\title{
特集 大腸癌と癌遺伝子
}

\section{VI＼cjkstart癌抑制遺伝子への細胞工学的アプローチ}

\author{
鳥取大学生命科学科細胞工学 \\ 堀川泉押村光雄
}

\begin{abstract}
正常細胞中には，癌細胞のもつ種々の形質を抑制する遗伝情報が存在する．このことが細胞雑種法を用、 た実験により示されたのが，癌抑制遺伝子研究の発端であった，近年，単一染色体移入法により，正常細胞 由来の I本の染色体を癌細胞敒導入することが可能となり，この手法を用いて癌抑制遺伝子についての染色 体レベルでの研究が進められている。これまでに大腸癌を含む種々の癌由来の細胞株を用いて得られた結果 は, 機能的に異なった数多くの癌抑制遗伝子が存在することを示し, 細胞雑種法や RFLP 解析による知見 を裹付けた。
\end{abstract}

索引用語：癌折制遗伝子, 細胞雑種法, 単一染色体移入法

\section{I.はじめに}

“正常細胞中に存在し，細胞の癌化に対して抑制的に 働き，癌細胞ではもはや久失あるいは不活化している遺 伝子”。このような遺伝子を広義に”癌㧕制賛伝子”之 定義できる.この分野の研究は，古く1969年の Harris らの細胞雑種法を用いた実験”に始まり，今日では分子 生物学的手法を駆使して, 実際にいくつかの癌抑制遗伝 子が単離されるに至っている。ここでは，単一染色体移 入法を主とする細胞工学的手法による癌抑制遺伝子に関 する研究について概説する.

\section{II. 癌抑制遺伝子の証抛}

正常紐胞が癌細胞一と進展する過程においては，癌化 に促進的に㗢く遺伝的变異を獲得するだけではなく，正 常細胞のもつ何らかの機能が失われる必要がある. 一般 に，正常細胞と癌細胞とを融合させてできた雑種細胞に おいては，もともと癌細胞がもっていた癌形質(とくに ヌードマウスーの造腫瘍性)が失われる1,2).このことは 正常細胞には冒頭で定義したような遺伝子が存在し，癌 細胞では寸でに消失した機能が補われ，癌形質の抑制を もたらしたと考えられる．さらにここのうな雑種細胞 を継代培養していくと，その中から澔形質を再獲得した 細胞が出現してくる。このような現象が，正常細胞由来 の特定染色体（あるいは特定染色体部位）の脱落々相関 していることが示され゙，この染色体上に癌抑制遺伝子 の存在が想定されてきた (図 1 ). 正常細胞から特定の
遺伝情報が消失寸ることが発癌に必要なステップである という考えに立てば，澏細胞において高頻度に久失の認 められる染色体部位が，癌抑制遺伝子の存在部位と考え られる. 実際，本特集の別項にその詳細が述べられて いるように，染色体解析あるいは RFLP (restriction fragment length polymorphisms) 解析 ${ }^{4)}$ の利用によっ て，癌細胞に扔いて染色体欠失が認められたもののいく つかは癌抑制遗伝子が存在することが証明されてきた.

\section{III. 微小核細胞融合法による単一染色体移入法}

前述のように雑種細胞に祆ける特定染色体の脱落と造 腫瘍性再獲得との相関，㐫るいは癌細胞に㧍ける特異的 染色体欠失部位から，染色体上における癌抑制遺伝子の 存在部位を推定することができる。癌抑制遗伝子の存在 をより強く裹ずけ，その働きを明らかにするための情報 を得る一手法として微小核細胞融合法に上る単一染色体 移入法がある，その概略を図 2 に示す，正常七卜線維茅 細胞由来の 1 本の染色体（優性遺伝子マーカーpSV2neo が組み込まれているので,この染色体を有する細胞はG 418耐性となる）を含むマウスA 9 細胞のライブラリー を作製する ${ }^{5}$. この細胞から微小核細胞（通常 1 本の染 色体を含む）を調整し癌細胞と融合した後，G418で選 択培蒩し耐性クローンを得る.この操作により，“正常 細胞由来の 1 本の特定染色体”を培養癌細胞株に移入す ることができる. 


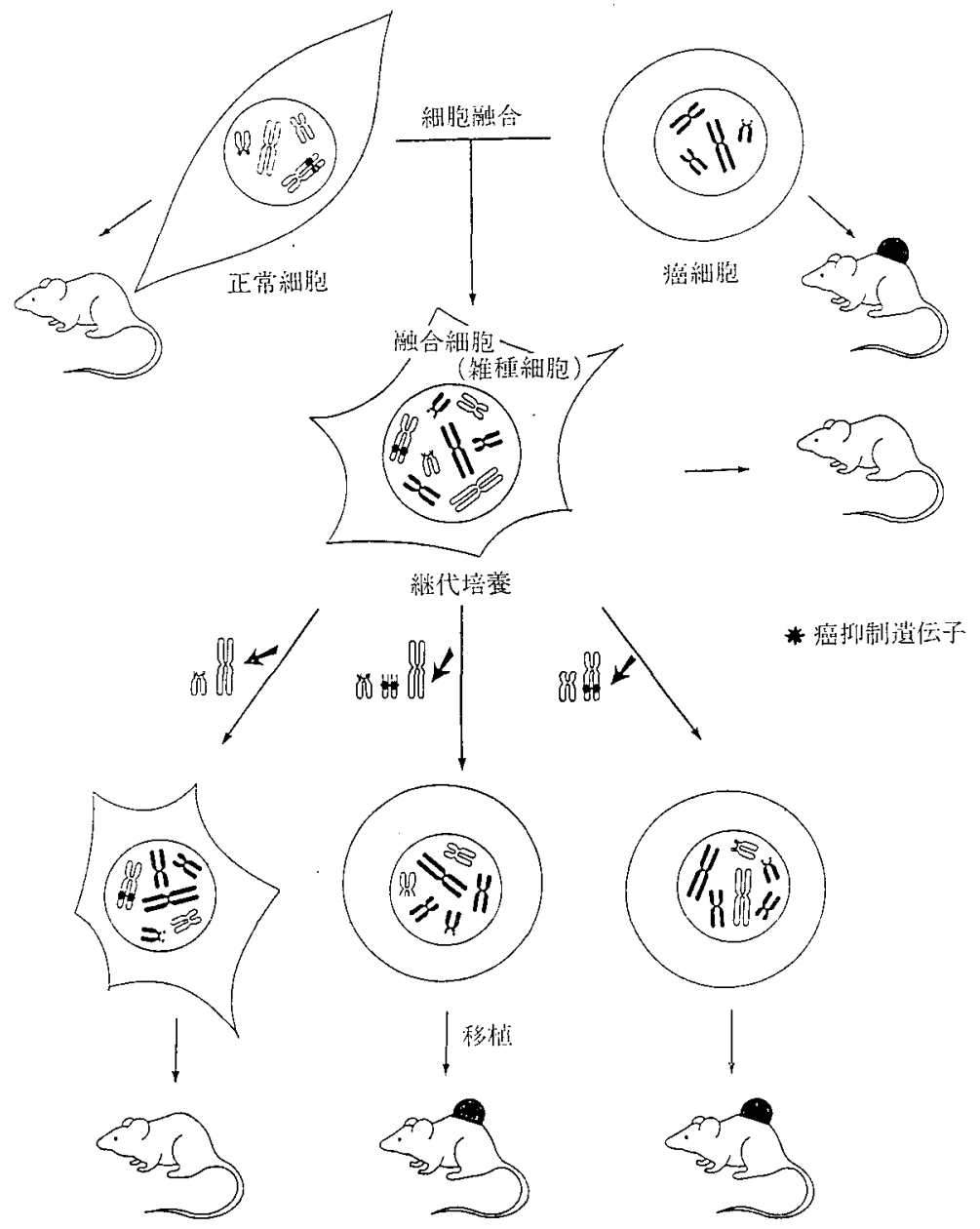

図 1 細胞雑種法による癌形澌抑制にかかわる染色体の検索 正常細胞と癌細胞とから形成される融合細胞は，癌細胞の造腫瘍性を含む種々の癌形質を 失う。継代培鼠に伴い出現する造腫劰性を再獾得した細胞では，特定の染色体（染色体部 位)の脱落がみられ，その染色体上に癌形質抑制にかかかる遗伝子の存在が示唆される。

\section{IV. 正常ヒト染色体移入による癌形質抑制}

これまでに単一染色体移入法を用いて得られた結果を 表1にまとめた。

I）細能雑種法, 染色対欠失部位検索の裹付け：細胞 雑種法から癌抑制遗伝子の存在が想定された染色体（子 宫頸癌の11番, 線維肉腫の1番など) および久失部位検 索から示唆された染色体 (膀胱癌・横紋筋肉腫の11番, 督細胞癌の 3 番など）について染色体移入を行ったとこ ろ，実際に癌形質を抑制することができたここことは， これらの染色体上に癌抑制遗伝子が存在寸ることを強く 支持するものである.さらに, 絾毛癌・子宮内膜癌など 癌抑制遗伝子が存在する上思われる染色体が不明であっ ても，任意の染色体を移入し抑制効果を示す正常七ト染
色体の同定を行うことより，逆に RFLP 解析のための 基礎データとすることができる．

II）多数の染色体上に癌抑制遺伝子の存在が示唆され る: 現在までに得られた結果だけでも，1番，3番，4 番， 5 番， 6 番， 7 番， 9 番，11番，18番，といった多 くのヒト正常染色体が，それぞれある特定の癌細胞に対 して癌形質抑制效果を示している，また，RFLP 解析 により示されてきたように，異なった癌タイプでは，同 じ染色体上の異なった部位に癌抑制遺伝子が存在する場 合もある.したがって同一染色体が抑制効果を有してい ても，必ずしもそれが同一の遗伝子の働きによると考え ることはできない．さらに抑制効果が，移入した 1 本の 染色体上の複数の遺伝子により制御されている可能性も 西り現段階では，正常細胞のゲノム上にいったい幾つの 
癌抑制遗伝子が存在しているかは不明である。

III）複数個の癌抑制遺伝子の関与 : 近年 RFLP 解析 により，ある特定タイプの癌に佶々て複数の染色体欠失 部位が同定され，たとえば大腸癌の $5 \mathrm{q} ， 17 \mathrm{p} ， 18 \mathrm{q}$, $22 \mathrm{q}^{18)}$ などのように癌の進展過程における複数個の癌抑 制遺伝子の不活性化の必要性が重要視されてきている. 正常染色体移入による結果は，この考えを強く支持して いる.すなわち，大腸癌・線維肉腫 - 子宮内膜癌 -子宮 頸癌（表中__）において，同一の癌細胞株に対して， 異なった染色体がそれぞれ単独で癌形質抑制効果を示し た.したがって，多段階発癌 (multistep-carcinogenesis） ${ }^{19)}$ の過程において複数の癌抑制遺伝子の不活性化 が関与してはいるが，いずれかの機能が補われるのみ で，癌細胞がより正常に近い状態に戻ることを示してい 万。

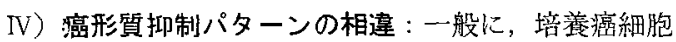
株は，a）無限增殖能を獲得し不死化している：b）接 触阻止を示さない重層状増殖・速い増殖速度・足場非依 存性增殖・低以血清要求性など in vitro の癌形翼を 獲得している：c）先疫不全マウスに腫瘍を形成寸る能 力（ヌードマウス八の造腫陽性）を有する，という性質 をもっている：これにもとずいて表】に示したように， 正常染色体移入による癌形質抑制効果を 3 タイプに分類 することかできた。すなわち，タイプ $\mathrm{A}=$ 癌細胞のもつ 無限増殖能を抑制する。皇結果，老死化を誘導する; タイプ $\mathrm{B}=$ 老死化を誘導する効果はないが， ヌードマウ スへの造腫瘍性および in vitro の癌形質を抑制する; タイプC=老死化を誘導せず, また in vitro の湾形質 も抑制しないが、ヌードマウスへの造腫瘍性を抑制す る，の3タイプである，とくに注目すべきことは，同一 の癌細胞株であってむ，染色体によって㧕制パターンが 異なる場合のあることである，たとえば，線維肉腫 $\mathrm{HT}$ 1080では 1 番染色体がタイプ $\mathrm{B}, 11$ 番染色体がタイプC, また子亳内膜䲣 HHUA では1番染色体がタイプA，6 番・ 9 番・11番染色体がタイプCのごとくである：この ような抑制タイプの相違は，これら染色体上に想定され る癌抑制遗伝子が機能的に異なっており，細胞内におけ る作用機序の相違を示唆しているものと考えられる.

表中の 1 番・6番・11番染色体に注目すると，これら が癌細胞の種類によって異なった抑制夕イプを示寸こと に気がっく、これは前述のように同一染色体上の異なっ た遺伝子の作用によるとも考えられるが，同一の遺伝子 であってもそれそれれの癌細胞によって異なったタイプの 抑制を示寸可能性す考えられる。また，表中タイプAの 膀肶癌に対して，11番染色体に抑制効果を認的ている が，異なった膀胱癌細胞株を用いた場合には1番染色体
優性遗伝子マーカー標識ヒト単一染色 体を含むマウスA 9 細胞

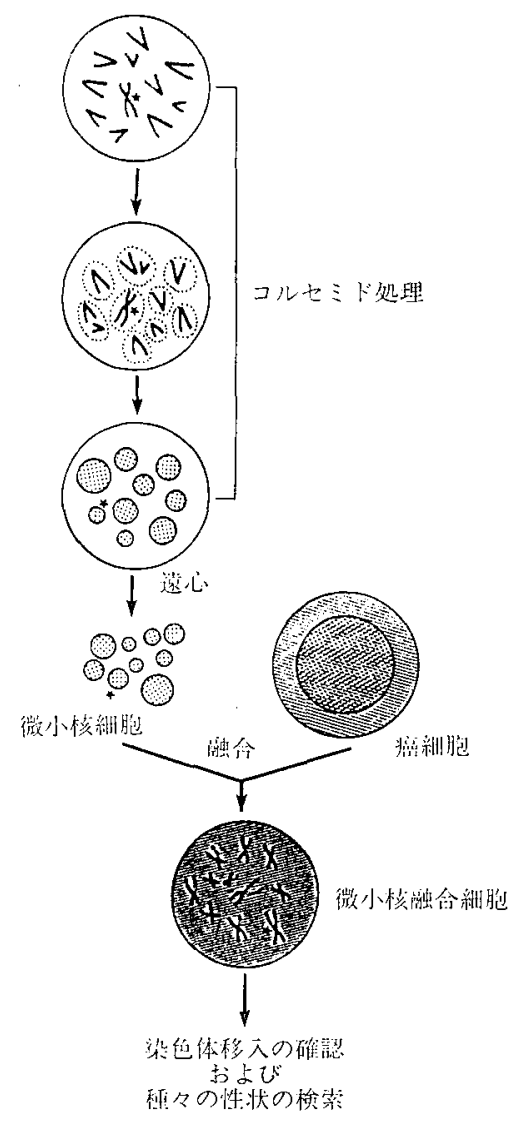

図 2 単一染色体移入法の概略

には抑制効果は無く，むしろ4番染色体移人で老死化の 誘導が認められた っても，個々の癌に执いては，必ずしも発癌の過程で同 一の癌抑制遺伝子の不活性化が関与しているとは限らな いことを示している。

ここで示したタイプ分類は，あくまでも培養癌細胞株 を用いた実験結果から導かれたものであり，この3つの タイプの性質が，実際の生体内での機能とどのように対 応しているかは全く不明である。また，すでにクロー二 ングされている癌抑制遺伝子のうち培養癌細胞株八の 導入実験の行われているもの（Rb 遗伝子20)，p 53遗伝 子211，Krev-1遺伝子22)）についてはタイプBの㧕制効 果を示しているようであるが，発現心゙タターに組み込ん で導入した場合と，より生理的な染色体という形で導入 した場合とを，必ずしも同一に論ずることはできない， 今後より多数の癌抑制遺伝子がクローニングされ，その 解析が進むにつれて，ここで示した分類の意義が明らか になっていくことが期待される。 
表 1 正常七ト染色体の激形㬴抑制効果

\begin{tabular}{|c|c|c|}
\hline 抑制効果のタイプ & 染色体；癌のタイプ（細胞株） & 文献 \\
\hline $\begin{array}{l}\text { タイプA } \\
\text { (細胞形態の变化および增殖速度の低下を示し，最終 } \\
\text { 的に細胞老死化を誘導する.） }\end{array}$ & 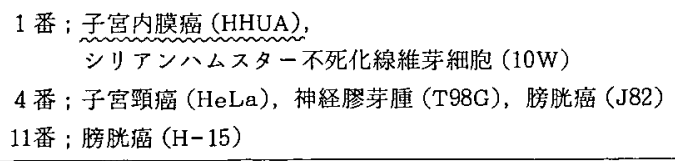 & $\begin{array}{l}6) \\
7) \\
8) \\
\text { 24) }\end{array}$ \\
\hline 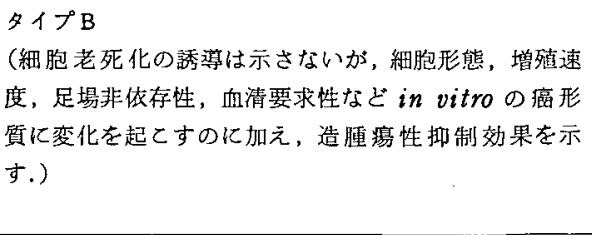 & 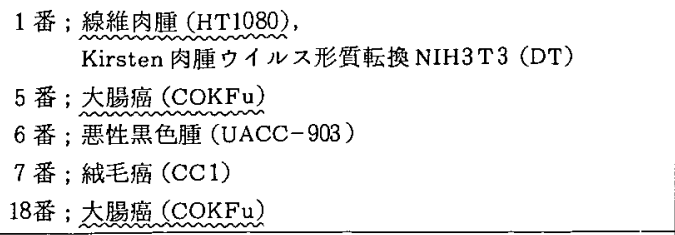 & $\begin{array}{l}9) \\
10) \\
11) \\
12) \\
\text { 24) } \\
11)\end{array}$ \\
\hline $\begin{array}{l}\text { タイプ } \\
\text { （老死化を誘導するととも，in vitro の癌形質を抑制 } \\
\text { するととあできないが，メードマウスへの造腫瘍性を } \\
\text { 抑制する.） }\end{array}$ & 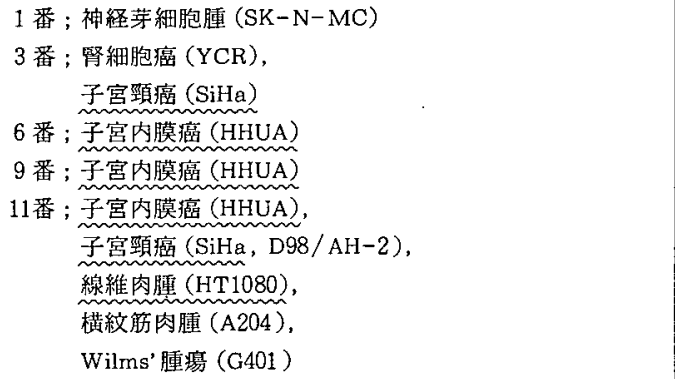 & $\begin{array}{l}\text { 24) } \\
\text { 13) } \\
\text { 24) } \\
6) \\
6) \\
6) \\
14,15) \\
\text { 9) } \\
\text { 16) } \\
17)\end{array}$ \\
\hline
\end{tabular}
；复数の染色体に抑制効果を認めている癌細胞株.

\section{V. 癌抑制遺伝子の機能消失機序}

従来，正常細胞から癌抑制機能が消失する場合には， 癌抑制遺伝子をコードするゲノム DNA の欠失，ある いは DNA 塩基置換などに伴ら遺伝子変異といった “genetic”な機構によるものが特に注目されてきた. 実際そのような概念が癌抑制遺伝子研究の根幹であり， 澞抑制遺伝子クローニングの出発点となった。しかしな がら, 従来の “genetic”な機構にくわえて, “epigenetic”な機構による癌抑制遺伝子の機能消失の可能性 を示唆する実験結果が示されてきた. Costa らは，正常 チャイニーズハムスターX染色体を有するマウスA 9 細 胞を染色体供与細胞として用いて，ニッケル処理で形質 転換したチャイニーズ八ムスター細胞に対して，単一染 色体移入を行った ${ }^{23)}$. その結果, 正常X染色体が細胞老 化を誘導することを報告した．注目すべきことは，a） 継代培養を重ねた A 9 細胞をX染色体の供与細胞として 用いた場合，正常染色体による抑制効果が明らかに減弱 した、しかし，b）この継代した供与細胞を 5 ーアザシ チジン（DNA の脱メチル化を訜起する）処理した後 に染色体移入を行うと，元のレベルの抑制効果を回復し た: この場合, 移入されるX染色体上の DNA の一次 構造配列に変暲あるい忺失が起こったとは考えにく
い. DNA のメチル化・脱メチル化に伴う頲伝子発垷の 減少・増加が抑制効果を左右していると思われる。

前述したように細胞雑種法による研究において，造腫 瘍性を再獲得した細胞の出現は，正常細胞由来の特定染 色体の脱落と相関していた．また単一染色体移入による 実験においても，癌形質抑制効果の認められた染色体移 入細胞の中から,癌形質を再獲得した細胞が出現寸るが， 多くの場合，この現象山移入染色体（あるい怔染色体部 位）の脱落を伴っている.この場合，癌形質抑制効果を もつ遺伝子の消失に起因し, “genetic”な機構による 癌抑制機能の消失によるものと考えられる.しかしなが ら，これとは異なった機構による癌形質の再獲得を示す 結果むある．前記の子宮頸㴦細胞株 SiHa に対して，正 常11番および 3 番染色体はそれぞれ単独で造腫瘍性抑制 効果をもつ，11番染色体移人 $\mathrm{SiHa}$ 細胞をヌードマウ スに移植したとき, 長い潜伏期の後, 稀に腫瘍が形成さ れる場合がある。このような腫瘍では移入された正常11 番染色体が脱落しており，上述の一般的な場合と同様で ある. 3 番染色体移入細胞でも，長い潜伏期をおいて稀 に腫湯が形成されるが，この腫瘍には移入された正常 3 番染色体が少なくとも形態上では完全な形で存在してい た。また，継代培養を重ねた 3 番染色体移入 $\mathrm{SiHa}$ 細 胞では，移入された 3 番染色体を保持しているにもかか 


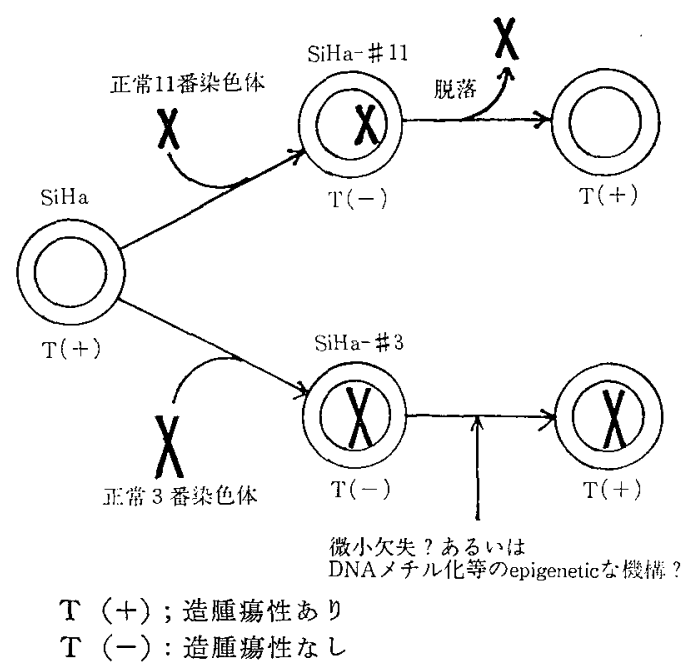

図 3 子宮頸癌細胞株 $\mathrm{SiHa}$ でみられた癌形質抑制 効果消失の 2 パターン

わらず，造腫烜性抑制効果が減弱し，染色体移入後早期 の細胞に比べて，短い潜伏期で高頻度の腫瘍形成が認め られた.このように11番染色体に関しては癌形質の抑 制・再獲得が移入染色体の存在・脱落と相関するのに対 して， 3 番染色体の場合，移入染色体が維持されたまま 澞形質の再獲得という性質の転換 (reversion) が起こっ た (図 3).この3 番染色体上江染色体解析やサザン法 で同定不能な小さな構造異常が起きている可能性は否定 しきれないが，上述の Costa らの結果と考えあわせ， 癌抑制遺伝子の“ “epigenetic” な機構による不活性化 の可能性を検索する貴重な資材になりらると考えられ る.

\section{VI. おわりに}

以上述へたように，単一染色体移入法は，癌抑制遗伝 子の存在する染色体を同定するための一次スクリーニン グ系として，非常に有効な手段である．また，澏抑制遗 伝子を染色体という生理的な形で（発現ベクターに組み 込んだ状態ではなく）細胞に導入し，その機能を検索す る材料を提供する．今後は，この系をいかにして実際の 遺伝子クローニングに結びつけていくか, また DNA卜 ランスフェクション法を用いた結果との対比を通して, 癌抑制遗伝子の実体とその機能解析のための基礎的デー 夕を提供してくれるであるう。

\section{文献}

1) Harris $H$, Klein $G$ : Suppression of malig. nancy by cell fusion. Nature $223: 363-368$, 1969
2) Harris $\mathrm{H}$ : The analyses of malignancy by cell fusion. Cancer Res $48: 3302-3306,1988$

3) Klinger HP, Kaelbling $M$ : Suppression of tumorigenicity in somatic cell hybrids. Cytogenet Cell Genet 42:225-235, 1986

4) 横田 淳: 染色体欠失 (allelic deletion), 癌 $88: 159-164,1988$

5) Koi M, Shimizu M, Morita $H$, et al: Construction of mouse A9 clones containing a single human chromosome tagged with neomycin-resistance gene via microcell fusion. Jpn J Cancer Res 80:413-418, 1989

6) Yamada H, Barrett JC, Oshimura M, et al: Multiple chromosomes carrying tumor suppressor activity for a uterine endometrial carcinoma cell line identified by microcellmediated chromosome transfer. Oncogene 5 : 1141-1147, 1990

7) Sugawara $O$, Oshimura $M$, Koi $M$, et al : Induction of cellular senescence in immortalized cells by human chromosome 1 . Science $247: 707-710,1990$

8) Ning Y, Pereira-Smith OM: Evidence for a cell senescence related gene ( $\mathrm{s}$ ) on human chromosome 4. IN VITRO 27:123, 1991

9) Kugoh $\mathrm{MH}$, Hashiba $H$, Oshimura $M$, et al: Suggestive evidence for functionally distinct, putative tumor-suppressor genes on chromosome 1 and 11 for a human fibrosarcoma cell line HT 1080. Oncogene 5: 16371644,1990

10) Yamada H, Horikawa I, Hashiba $H$, et al : Normal human chromosome 1 carries suppressor activity for various phenotypes of a Kirsten murine sarcoma virus-transformed NIH/3T3 cell line. Jpn J Cancer Res 81 : 1095-1100, 1990

11) Tanaka $K$, Oshimura $M$, Miyaki $M$, et al : Suppression of tumorigenicity in human colon carcinoma cells by introduction of nor. mal chromosome 5 or 18 . Nature $349: 340-$ 342, 1991

12) Trent JM, Stanbridge EJ, McBride HL, et al: Tumorigenicity in human melanoma cell lines controlled by introduction of human chromosome 6. Science $247: 568-571,1990$

13) Shimizu M, Yokota J, Mori N, et al : Introduction of normal chromosome $3 \mathrm{p}$ modu. lates the tumorigenicity of a human renal cell carcinoma cell line YCR. Oncogene $5: 185-194,1990$

14) Koi M, Morita $H$, Yamada $H$, et al: Normal human chromosome 11 suppresses tumorigenicity of human cervical tumor cell line SiHa. Mol Carcinogen 2:12-21, 1989

15) Saxon PJ, Srivatsan ES, Stanbridge EJ : Introduction of human chromosome 11 via 
microcell transfer controls tumorigenic expression of HeLa cells. EMBO J 5 : 34613466, 1986

16) Oshimura $M$, Kugoh $H$, Koi $M$, et al : Transfer of a normal human chromosome 11 suppresses tumorigenicity of some but not all tumor cell lines. $J$ Cell Biochem $42: 135-142,1990$

17) Weissman B, Saxon PJ, Pasquale SR, et al: Introduction of a normal human chromosome 11 into a Wilms' tumor cell line controls its tumorigenic expression. Science $236: 175-180,1987$

18) Fearon ER, Vogelstein B: A genetic model for colorectal tumorigenesis. Cell 61 : 759-767, 1990

19）堀川泉, 押村光雄：癌抑制遺伝子. 癌と化療
$18: 153-159,1991$

20) Huang, H-JS, Yee J-K, Shew J-Y, et al : Suppression of the neoplastic phenotype by replacement of the RB gene in human cancer cells. Science $242: 1563-1566,1988$

21) Baker SJ, Markowitz S, Fearon ER, et al : Suppression of human colorectal carcinoma cell growth by wild-type p53. Science 249 : 912-915, 1990

22) Kitayama $H$, Sugimoto $Y$, Matuzaki $T$, et al: A ras-related gene with transformation suppressor activity. Cell 56:77-84, 1989

23) Klein CB, Conway $K$, Costa $M$, et al : Senescence of nickel-transformed cells by an $\mathrm{X}$ chromosome: Possible epigenetic control. Science 251: 796-799, 1991

24）堀川泉，久郷裕之，押村光雄ほか：未発表.

\title{
Studies on Tumor-suppressor Genes by Monochromosome Transfer
}

\author{
I. Horikawa and M. Oshimura \\ Department of Molecular and Cell Genetics, School of Life Sciences, \\ Faculty of Medicine, Tottori University, Tottori
}

The existence of tumor-suppressor genes has been primarily suggested by three lines of evidences: 1) Various transformed phenotypes are often suppressed in hybrids between normal and tumorigenic cells, and re-expression of the phenotypes in the hybrids is associated with loss of specific chromosomes. ; 2) non-random chromosome deletions in a variety of tumors; 3) loss of heterozygosity in specific chromosomal regions in a variety of tumors. Results from transfer of candidate normal human chromosomes that might carry tumorsuppressor genes into various tumor cell lines, strongly support an idea that multiple tumorsuppressor genes are involved in a carcinogenic process of a given tumor. Three types of suppression were observed; a) Induction of cellular senescence, b) Suppression of both the in vitro transformed properties and tumorigenicity, c) Suppression of the tumorigenicity. These findings further suggest the existence of functionally distinct tumor-suppressor genes. The loss of a suppressive function can be either genetic or epigenetic. 